УДК: 811.11 .112

ГРНТИ: 16.01 .11

\title{
LINGUODIDACTIC ASPECT OF COMMUNICATION CULTURE
}

DOI: $10.31618 /$ ESU.2413-9335.2020.7.70.571

Uteshova Zernegul Khurmetullaevna

PhD., docent, at the faculty of foreign languages

English language teacher at English language and literature department

Karakalpak state university named after Berdakh

Nukus, Karakalpakstan, Uzbekistan

(Phone number:+998913707755)

\section{ЛИНГВОДИДАКТИЧЕСКИЙ АСПЕКТ КУЛЬТУРЫ КОММУНИКАЦИИ}

\author{
Утешова Зернегуль Хурметуллаевна \\ Доктор педагогических наук., доиент, \\ на факультете иностранных языков \\ Преподаватель английского языка \\ на кафедре английского языка и литературы \\ Каракалпакский государственный университет имени Бердаха \\ Нукус, Каракалпакстан, Узбекистан
}

\begin{abstract}
The article depicts some problems of communication culture and speech culture in the works of scientists. In the introduction, concepts of "speech culture", as well as "culture of communication", which includes the culture of thinking have been analyzed by providing with examples. Also, in the main part, linguodidactic speech of culture, and accepted rules of behavior in various speech acts of communication are explained by using descriptive analysis method.
\end{abstract}

\section{АННОТАЦИЯ}

В статье освещены некоторые проблемы культуры общения и культуры речи в трудах ученых. Во введении были проанализированы понятия «речевая культура», а также «культура общения», которая включает в себя культуру мышления, на примерах. Также в основной части лингводидактическая речь культуры и общепринятые правила поведения в различных речевых актах общения объясняются с помощью метода описательного анализа.

Key words: communication culture, speech culture, ethical standards, linguistic knowledge, extra-linguistic knowledge, language tools.

Ключевые слова: коммуникативная культура, речевая культура, этические стандарты, лингвистические знания, экстралингвистические знания, языковые инструменты.

Language is a socio-psychological phenomenon that contains the whole rich diversity of spiritual and material forms of human life and is its urgent need. In material terms, communication is determined by the need and necessity of joint participation of people in the production of material goods. In spiritual life, the central place is occupied by the need to form a personality of the new world, the development of its ideological and moral qualities and the need for a person to acquire social experience, familiarize him with cultural values and master the principles and norms of behavior in society, i.e. in a social environment. Thus, language and speech are different phenomena, but they cannot exist without each other and are closely interrelated. Therefore, we cannot build a correct expression that meets our communicative goals without knowing the language. And on the other hand, thanks to speech, the development of the language system takes place: after all, it is in speech that those random deviations from linguistic norms arise, which can then become regular and become fixed in the language. Culture as a social phenomenon also represents the values of accumulated and accumulated definitions by a community of people, has a historical genesis, and plays a role in the formation of a separate human person. Some problems of communication culture and speech culture were highlighted in the works of G.O.Vinokur [5,p.254], V.V.Vinogradov, V.G.Kostomarov [1,p.64-65], L.I.Skvortsov, A.A.Leontiev [2,p.7-15], I.A.Winter, N.I.Formanovskaya, L.G.Smirnov, L.A.Vvedenskaya, M.N.Nochevnik and others. Based on the above works, we can say that culture of communication includes the culture of speech. In turn, linguodidactic speech culture includes: knowledge of the real system of language in its historical development and the ability to communicate on this basis, the ability to give normative assessments of linguistic phenomena, and carry out scientifically based regulatory linguistic functions.

In the dictionary of linguistic terms speech culture is described as "the life of a society in a certain era (an objective historical point of view) and which determines, on the basis of the rule of using the language as the main means of communication between people, an instrument for the formation and expression of thought (a regulatory point of view)" [6].

According to V.G.Kostomarov, A.A.Leontiev and B.S.Schwarzkopf, the norm in the theory of the culture 
of speech, acts as a correlator of the system and as a combination of the most suitable language tools for serving society. In this case, it acts as a stylistic concept, expressed by the features of linguistic use and associated with the social role relations of the participants in the communicative act, therefore they speak of the stylistic diversity of the form of speech.

Thus, from the standpoint of the theory of speech acts, the culture of speech is such a choice and such an organization of linguistic means that, taking into account the situation of communication and observing the proper linguistic, communicative and ethical standards, can provide the greatest effect in achieving the set communicative goals. Studying a foreign language, students must master its literary norm, but the literary norm may fluctuate depending on the type of speech (written and spoken; official and unofficial). In oral speech, for example, words, syntactic constructions and others are used, which contradict the literary norm of the language.

Therefore, one should proceed from the variability of the speech utterance, which was rightly explained by P.V.Sysoev about the advantage in using a foreign language of the prescriptive and discriptive grammar [3,p.9-32]. Language proficiency, according to L.I.Skvortsov, assumes, in principle (in a bilateral act of communication), understanding and the possibility of producing any number of phrases and constructions [4,p.27]. But it should be remembered that in the production of "phrases and constructions" one should proceed from the language norm of the language being studied.

However, we could not violate the norms of the language, follow all the rules of ethics of communication, but at the same time create unsatisfactory texts.

Therefore, in the culture of speech, the communicative component plays an important role in achieving communication goals, because for each goal - its own funds. For adequate communication, a person must be able to perceive the text and correctly interpret it and, thereby, exchange thoughts. For this, students need linguistic and extra-linguistic (extra-linguistic) knowledge. Depending on personal relationships, the content of speech also fluctuates (modulated). With a communication partner you can talk with both an adult and a child, use various topics, arguments, evidence, and various language tools from standard (normative) to non-standard.

Consequently, the culture of speech is only part of the broader concepts of "speech culture", as well as "culture of communication", which includes the culture of thinking and the psychological culture of communication. For example, L.I.Skvortsov notes that "if you want to achieve effective communication, strive in every way to emphasize the dignity of the interlocutor" [4,p.45]. His words clearly speak of psychological culture, and about the psychological impact.

Now we will consider the culture of communication between representatives of two different ethnic groups, connected by the cultural and instrumental plans that were defined by L.V.Minaeva [7,p.176-177]. The cultural plan is an informational and cultural reserve that each participant in communication possesses, all that information accumulated by a person throughout his previous activities in a single community. Here we are talking about culturally determined value structures of communication participants, accepted rules of behavior in various speech acts (situations) of communication, and others. Information about reality and about oneself, about the mechanisms of behavior of each communicant have their own specific features in different societies, therefore, the information reserves of partners can only partially overlap, communicants use only activated information relevant to this speech act. It should be noted that the mental activity of partners (worldview, mentality, character, education) is connected with this information. In the course of such communication, the model of the world of speaker or listener overlaps, and speech acts as a "conductor of information". Due to the fact that communication participants belong to different "worlds", they must have a common code, common knowledge and others, otherwise the message will not be adequately interpreted by listener and even the reflection of the speaker's world model will be distorted. The instrumental, which is a set of verbal and non-verbal means for communicating at the disposal of communicants, is closely intertwined with the cultural plan. It is known that a set of verbal and non-verbal means also has its own culturally determined specific features. Many researchers have proven that there is a certain culturally-conditioned difference in the interpretation of many concepts, where some of the information overlaps (it is not clear to a representative of another culture) even in words that have a similar concept (friendship, homeland). The evidence is the work of S.G.Terminasova, V.V.Vorobyova, V.A.Maslova [8,p.80]. Based on these works, we can argue that in addition to the basic logical picture of the world that arises on the basis of social production practice in the unity of two stages of thinking (living contemplation and abstract thinking), a certain side linguistic picture of the world is formed, which does not always correspond to the first. This phenomenon is explained by E.M.Vereshchagin and V.G.Kostomarov as follows: "the picture of the world as a whole is created by knowledge, and not by language, and the verbal image of an object or relationship acts as a form of logical reflection of being, as an additional national background, above which a universal human logical image rises" [1,p.6].

Therefore, in addition to the realities of culture, for successful communication it is necessary to know the features of the linguistic picture of the world characteristic of the language being studied.

To sum up, analyzing the problems of communication culture, we conclude that it involves knowledge of nationally determined behavior scenarios and the ability to use all language tools that are optimal for a given speech situation in various functional speech styles. This thesis proceeds from the fact that every national language is a peculiar, distinctive style of national expression, because “... each language reflects the culture of people who speak it". 


\section{References}

1. Kostomarov V.G. Speech culture and style. M., 1960. p.66;

2. Leontiev A.A. The future of language as a problem of speech culture // Questions of speech culture. 1967. No.8. p.7-15.

3. Sysoev P.V. Communicative-ethnographic approach to teaching a foreign language and culture: new challenges and new opportunities in the XXI century // Foreign languages at school. 2015. No. 1. p.9-32;

4. Skvortsov L.I. Fundamentals of speech culture: reader / comp. L.I. Skvortsov. - M.: Higher School, 1984. $-312 \mathrm{p}$.
5. Vinokur G.O. Language culture. M.,Federation. (Reprint:M.: Labyrinth, 2006.254 p.) 1929.-336 p;

6. Matthews P.H. The concise Oxford dictionary of linguistics. ( $2^{\text {nd }}$ ed). 2007;

7. Minaeva L.V., Salieva L.K, T.I.Borisenko, T.V.Valentei and others. Speech communication in modern society /Ed./ NOPAYAZ M, 2002.354 p.

8. Maslova V.A. Linguoculturology. Introduction: textbook. manual for undergraduate and graduate programs / V.A.Maslova; open ed. W.M.Bakhtikireeva. - 2nd ed., Revised. and add. Moscow: Yurayt, 2018. - 206 p. 